\title{
PELATIHAN KETERAMPILAN KOMPRES TEPID WATER SPONGE SEBAGAI UPAYA PENCEGAHAN KEJANG DEMAM ANAK DIMASA PANDEMI COVID - 19
}

https: / /doi.org/10.33024/jkpm.v4i6.4544

\author{
Siti Nur Solikah ${ }^{1 *}$, Sunaryo Joko Waluyo ${ }^{2}$ \\ 1,2 Jurusan Keperawatan Politeknik Insan Husada Surakarta \\ Disubmit: 15 Juni 2021 Diterima: 24 Juni $2021 \quad$ Diterbitkan: 01 Desember 2021
}

Email Korespondensi: sitinurs@akperinsanhusada@ac.id

\begin{abstract}
ABSTRAK
Penyakit infeksi pada anak selalu ditandai dengan demam yang akan berlanjut terjadi kejang demam pada anak apabila tidak segera ditangani. Metode kompres dengan water tepid sponge efektif dalam menurunkan demam pada anak sehingga mampu mencegah terjadinya kejang demam. Kondisi pandemi COVID 19 membuat masyarakat takut untuk memeriksakan anak ke Palayanan Kesehatan masyarakat. Ibu sering mengalami kepanikan saat anak kejang demam sehingga pengetahuan dan keterampilan penanganan demam dirumah sangat dibutuhakn masyarakat di masa pandemic COVID-19. Kader Posyandu sebagai penggerak kesehatan di masyarakat diharapkan mempunyai pengetahuan dan pemahaman yang lebih untuk bisa meningkatkan derajad kesehatan mayarakat. Tujuan setelah pelatihan singkat melalui whatsapp group discussion diharapkan dapat meningkatkan pengetahuan dan keterampilan dalam penanganan kejang demam dirumah. Adapun kegiatan yang dilakukan berupa pelatihan singkat menggunakan media whatsapp, video pembelajaran keterampilan kompres WTS serta booklet penaganan kejang demam. Hasil evaluasi kegiatan terdapat peningkatan pengetahuan dan keterampilan kompres pada kader Posyandu Wilayah Kerja Puskesmas Sangkrah Surakarta.
\end{abstract}

Kata Kunci: water tepid sponge, kader posyandu, pademi COVID - 19.

\begin{abstract}
Fever marks an infectious disease in children. it can progress to febrile seizures if not treated immediately. The compressing method with the tepid water sponge effectively reduces fever in children to prevent febrile seizures. The COVID-19 pandemic has made people afraid to check their children at the community health service. Mothers often experience panic when their child has a febrile seizure, so the community very much needs that knowledge and skills in handling fever at home during the COVID-19 pandemic. Posyandu cadres, as health drivers in the community, are expected to have more knowledge and understanding to be able to improve the level of public health. After short training through WhatsApp group discussion, the goal is to increase knowledge and skills in handling febrile seizures at home. The activities carried out were short training using WhatsApp media, video learning of WTS compress skills and booklets for handling febrile seizures. The activity evaluation results showed an increase in knowledge and skills in compressing the Posyandu cadres in the Sangkrah Surakarta Health Center Work Area.
\end{abstract}

Keywords: Water Tepid Sponge, Posyandu cadres, COVID-19 pandemic 


\section{PENDAHULUAN}

Masalah kesehatan anak di Indonesia masih mendapat prioritas dalam perencanaan pembangunan di Indonesia (Prasetyo \& Siagian, 2017). Berbagai penyakit pada anak seperti pneumonia, campak, diare dan malnutrisi disebabkan karena infeksi virus dan bakteri yang selalu ditandai dengan tanda dan gejala terjadinya demam pada anak (Marwan, 2017). Penyakit yang ditandai dengan demam dapat menyerang system tubuh (Arifuddin Adhar, 2016). Kejadian ini terjadi saat tubuh mengalami kenaikan suhu antara $38-38,9^{\circ} \mathrm{C}$, yang disebabkan karena adanya infeksi pada jaringan ekstrakranial seperti tonsillitis, otitis media akut dan brochitis (Wulandini et al., 2019). WHO memperkirakan terdapat lebih dari 21,65 juta penderita kejang demam dan lebih dari 216 ribu diantaranya meninggal. Selain itu di Kuwait dari 400 anak berusia 1 bulan - 13 tahun dengan riwayat kejang, yang mengalami kejang demam sekitar 77\% (WHO, 2013 dalam Untari 2015).

Pertolongan pertama dirumah pada anak dengan kejang demam dilakukan untuk mencegah cedera dan komplikasi yang serius pada anak. Salah satu tindakan yang digunakan untuk menurunkan panas adalah dengan Water Tepid Sponge (WTS). WTS merupakan suatu prosedur untuk meningkatkan kontrol kehilangan panas tubuh melalui evaporasi dan konduksi, yang dilakukan pada pasien yang mengalami demam tinggi. Tujuan dilakukan tindakan WTS yaitu untuk menurunkan suhu tubuh pada pasien yang mengalami hipertermia (Wardiyah et al., 2016).

Kondisi pandemi COVID-19 membuat masyarakat menjadi khawatir dengan Kesehatan anaknya. Ibu dengan balita dirumah pada masa pandemi COVID-19 sering mengalami cemas dan panik saat mendapati kondisi anak mengalami kejang demam (Yuningsih, 2020). Kebiasaan di masyarakat saat anak kejang adalah dengan memberikan minuman kopi, memberikan sendok kedalam mulut anak dan sering berkerumun menolong anak. Pertolongan yang cepat dan tepat sangat dibutuhkan untuk menolong anak dari resiko kejang demam (Suparjo, Fatchurrozak H, Nurcholis, 2019).

Kondisi masyarakat tersebut menjadi alasan diperlukannya posyandu sebagai pembelajaran non formal (Juwita, 2020). Kegiatan penyuluhan kesehatan pada kader Posyandu tentang pengetahuan dan keterampilan penanganan kejang demam secara mandiri di rumah melalui keterampilan kompres water tepid sponge (WTS) terutama di masa pandemi COVID-19 (Setyani \& Khusnal, 2013). Tujuan akhir kegiatan yaitu pengetahuan dan ketrampilan kader Posyandu dalam penanganan demam dapat meningkat, dimana pengetahuan yang diperoleh bisa ditransfer kepada masyarakat secara umum dalam hal ini adalah ibu-ibu yang mempunyai balita di wilayah Kelurahan Sangkrah Surakarta untuk mencapai derajad kesehatan masyarakat yang optimal (Pebrisundari, 2019). 
2. MASALAH

Berdasarkan analisis situasi yang dilakukan bersama mitra maka terdapat beberapa permasalahan yang harus ditangani diantaranya adalah: 1). Banyaknya kejadian kejang demam di wilayah Sangkrah akibat penyakit infeksi maka kader Posyandu sebagai garda terdepan kesehatan anak di masyarakt perlu mendapatkan pengetahuan dan keterampilan yang baik 2). Kurangnya pengetahuan kader Posyandu tentang kejang demam 3). Kurangnya pengetahuan dan pengalaman keterampilan penanganan kejang demam dirumah maka perlu adanya praktek demonstrasi water tepid sponge (kompres hangat) yang benar sebagai langkah awal penaganan demam dirumah agar tidak terjadi kejang demam di masa pandemi covid-19.

Indikator keberhasilan pada pengabdian masyarakat ini adalah kader posyandu mempunyai pengetahuan dan keterampilan yang baik dalam penanganan kejang demam dirumah, kader posyandu mampu mempraktekkan kembali keterampilan kompres WTS pada anak dan pengetahuan dan keterampilan keluarga dalam menangani demam dirumah menjadi lebih baik.

Evaluasi dalam kegiatan ini adalah evaluasi sebelum pelatihan berupa pre-test, pada saat pelaksanaan kegiatan berupa tanya jawab dan diskusi setelah pemberian materi dan praktek berupa post-test tentang kejang demam dan penanganan dengan water tepid sponge. Tim pengabdian masyarakat juga melaksanakan monitoring evaluasi melalui pengumpulan video keterampilan water tepid sponge dari kader Posyandu.
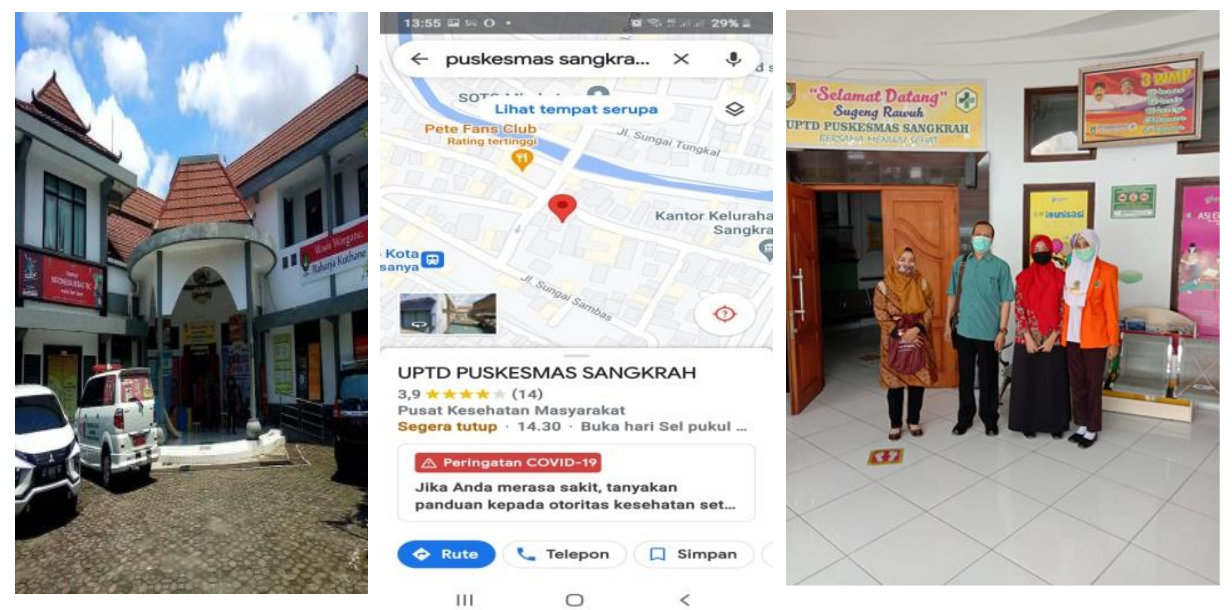

Gambar. 2.1 Peta Lokasi Kegiatan Pengabdian Kepada Masyarakat

\section{METODE}

Metode yang digunakan pada kegiatan pengabdian masyrakat ini adalah active and participatory learning melalui beberapa tahap yaitu tahap persiapan, tahap pelaksanaan yang terdiri dari observasi tingkat pengetahuan melalui pretest, memberikan pelatihan melalui pemberian materi kejang demam melalui booklet yang dikirim melalui media WAG. Selanjutnya responden diberikan materi praktek terkait penanganan kejang demam dengan metode kompres water tepid sponge berupa video pembelajaran serta 
pada tahap tahap evaluasi dilakukan pengukuran pengetahuan dan keterampilan berupa postest, pendampingan dan evaluasi hasil video yang dibuat oleh kader Posyandu dirumah.

a. Tahap Persiapan

Tahap persiapan dalam kegiatan ini adalah pembuatan pre planning kegiatan edukasi pada kader, pembuatan booklet, penyusunan kuesioner keterampilan kompres WTS, penyusunan SOP kompres WTS, pembagian peralatan kompres dan terakhir membuat video pembelajaran kompres WTS yang dilaksanakan oleh dosen di laboratorium keperawatan. Booklet dan video digunakan sebagai materi penyuluhan secara online melalui media whatsapp group discussion (WAG).
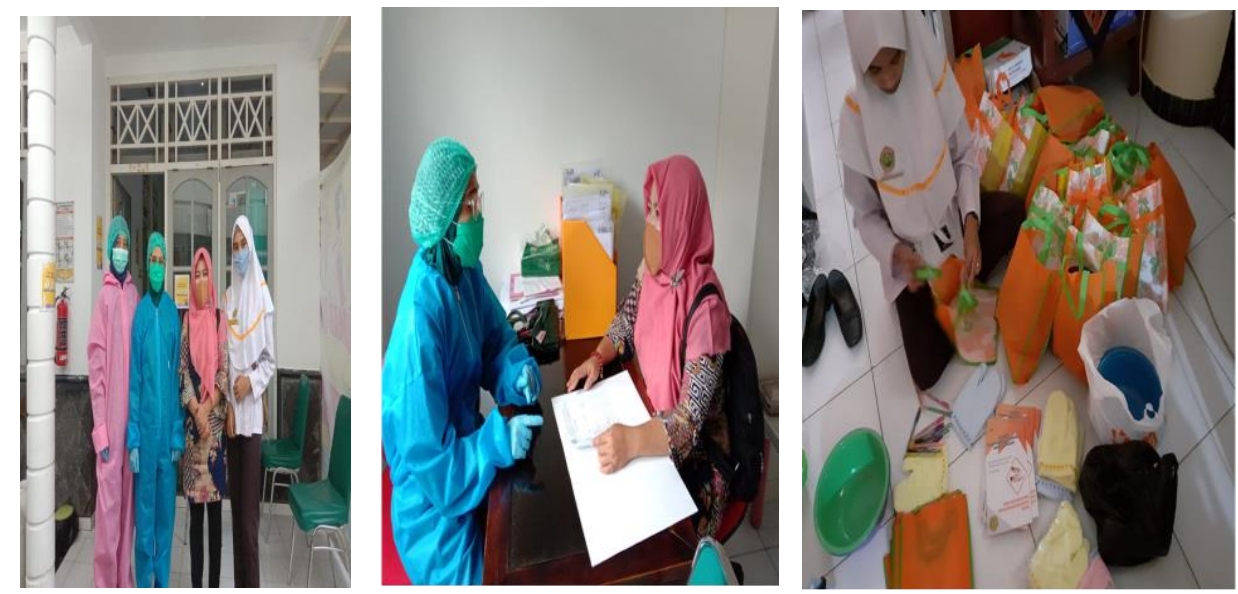

Gambar 2.2 Koordinasi dan pembagian alat dengan Puskesmas

b. Tahap Pelaksanaan

Tahap pelaksanan pada kegiatan ini adalah permohonan surat ijin kegiatan dari DKK Surakarta selanjutnya diteruskan pada Kepala Puskesmas Sangkrah Surakarta. Kepala Puskesmas menunjuk bidan desa untuk koordinasi kegiatan pengabdian masyarakat. Kegiatan pelatihan keterampilan kompres WTS ini dilaksanakan selama 1 bulan ( 4 kali pertemuan tiap minggu) secara terjadwal tiap hari Jumat pada bulan Maret 2021 dengan jumlah responden yang mengikuti kegiatan sebanyak 15 kader. Media yang digunakan selama 4 kali kegiatan penyuluhan Kesehatan dilakukan melalui whatsapp group discussion (WAG).

Adapun jadwal kegatan setiap pertemuan adalah sebagai berikut: pertemuan ke-1: Sosialisasi program pelatihan dan perkenalan dari tim pengabdian masyrakat Insan Husada Surakarta sekaligus pemberian pre test pada peserta. Pertemuan ke-2: penyampaian materi tentang kejang demam melalui booklet yang dikirim di WAG. Pertemuan ke-3: demonstrasi keterampilan kompres WTS melalui video pembelajaran. Pertemuan ke-4: pengumpulan video kompres yang dilakukan oleh kader dirumah serta pelaksanaan post-tes pengetahuan dan keterampilan kader setelah diberikan penyuluhan secara online melalui WAG. 


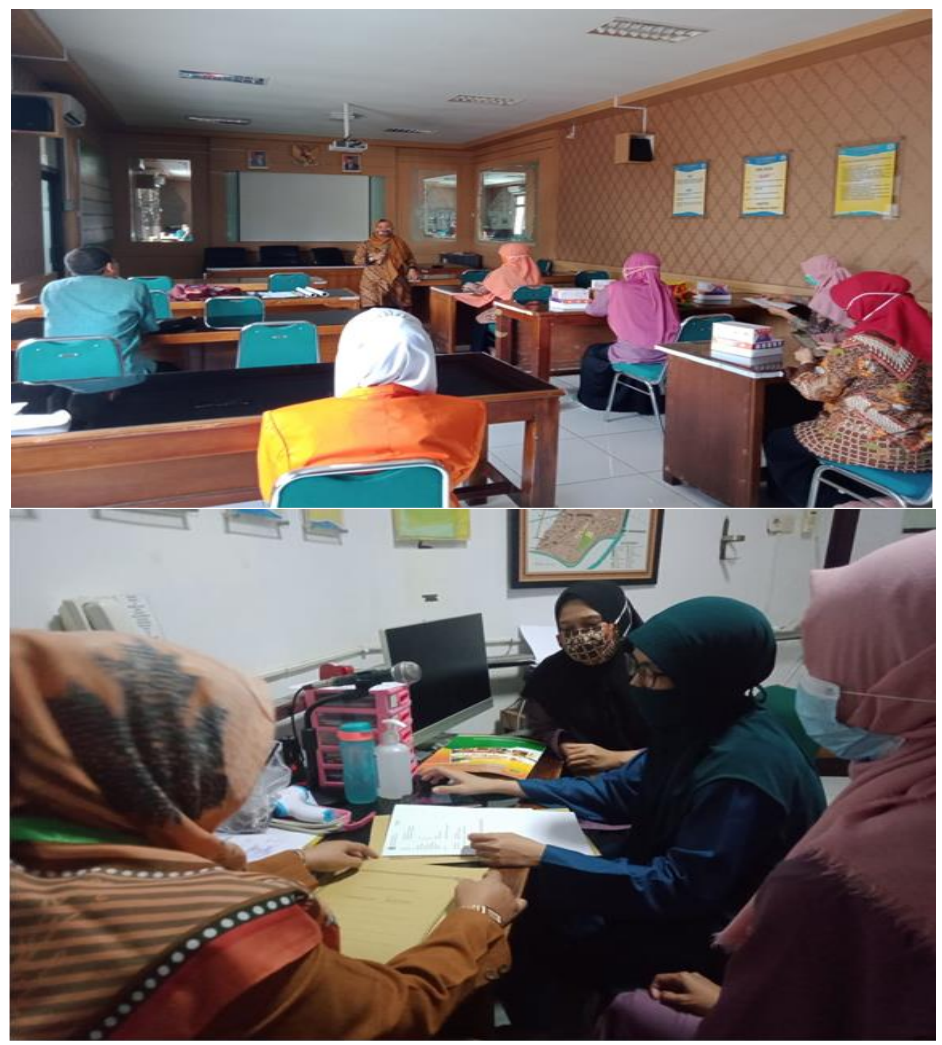

\section{Gambar 2.3 FGD kegiatan PKM di Puskesmas Sangkrah Surakarta}

c. Evaluasi

1) Struktur

Peserta yang hadir dalam WAG sebanyak 15 peserta kader Posyandu Wilayah kerja Puskesmas Sangkrah Surakarta. Selama kegiatan pertemuan 1-4 semua peserta aktif bertanya dan berkomunikasi dengan baik. Setiap kali pertemuan dilakukan selama 100 menit, digunakan untuk membaca/memahami materi yang diberikan serta untuk diskusi dan tanya jawab melalui WAG. Peserta dapat memahami apa yang disampaikan dosen. Bidan desa ikut memfasilitasi kegiatan dalam WAG.

2) Proses

Pelaksanaan kegiatan dilaksanakan tiap hari Jumat pukul 09.00-10.40 WIB sesuai dengan jadwal yang telah direncanakan. Semua peserta pelatihan mengisi google form pre-tes dan post-tes yang diberikan oleh tim pengabdian masyarakat. Pada tahap evaluasi juga dilakukan pendampingan kader dimasa pandemik dengan mengirimkan video pelaksanaan kompres WTS yang akan dinilai oleh peneliti dan bidan desa. Diharapkan dengan adanya pendampingan, pengetahuan dan ketrampilan kader Posyandu tentang penaganan kejang demam melalui kompres WTS akan meningkat. 


\section{HASIL DAN PEMBAHASAN}

Pelaksanaan kegiatan pelatihan keterampilan kompres Water Tepid Sponge (WTS) pada Kader Posyandu Wilayah kerja Puskesmas Sangkrah Surakarta dilaksanakan pada 8 sampai 29 Mei 2020 melalui media online whatsapp group discussion (WAG) selama 4 kali pertemuan secara online dilaksanakan tiap hari jumat dengan durasi 100 menit tiap pertemuan.

Media dan alat yang digunakan adalah booklet, video kompres WTS, perlatan kompres WTS. Metode yang digunakan selama pelatihan adalah tanya jawab diskusi dengan bahan materi dari booklet dan video pembelajaran kompres WTS. Video pembelajaran kompres bisa diakses di link berikut: https://www. youtube.com/watch?v=SGX6L8AUZtA

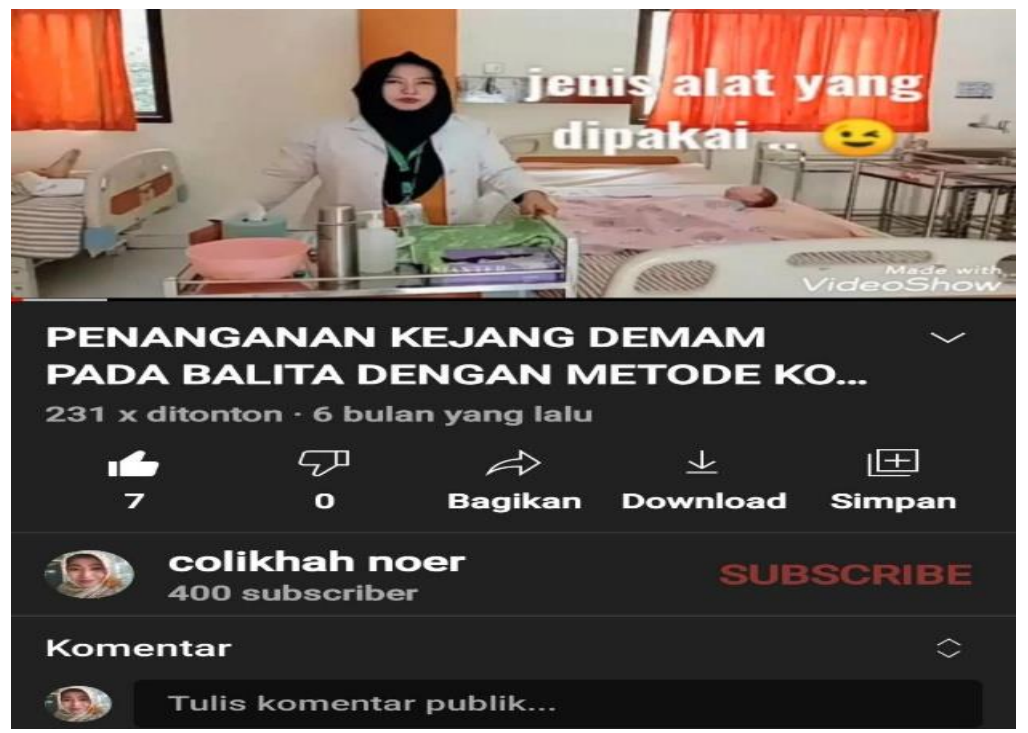

Gambar 2.4 Tutorial praktek kompres water tepid sponge

Kegiatan pre-tes dan post-tes dilakukan melalui pengisian google form yang dikirim melalui WAG.
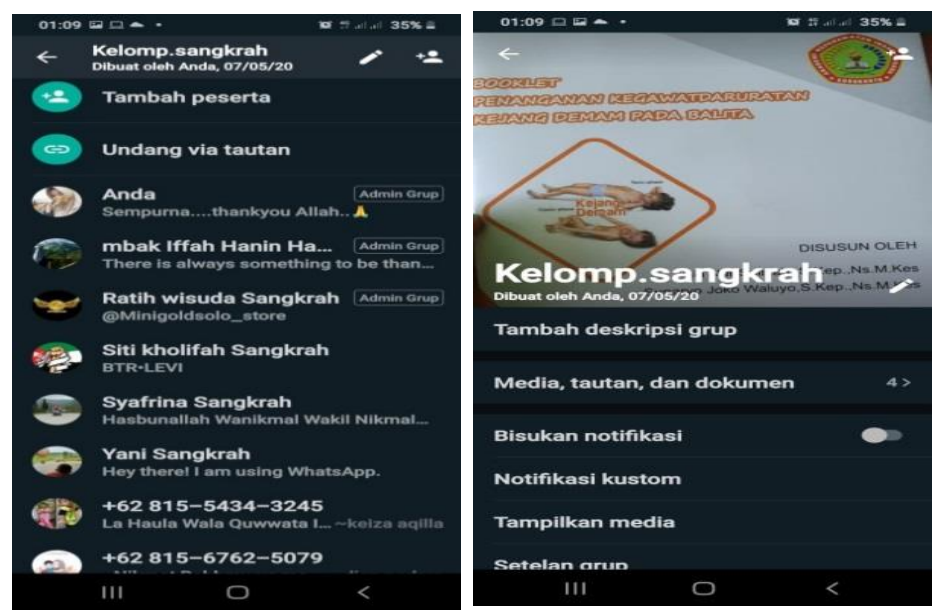

Gambar 2.5 Foto Kegiatan PKM secara online melalui WAG 


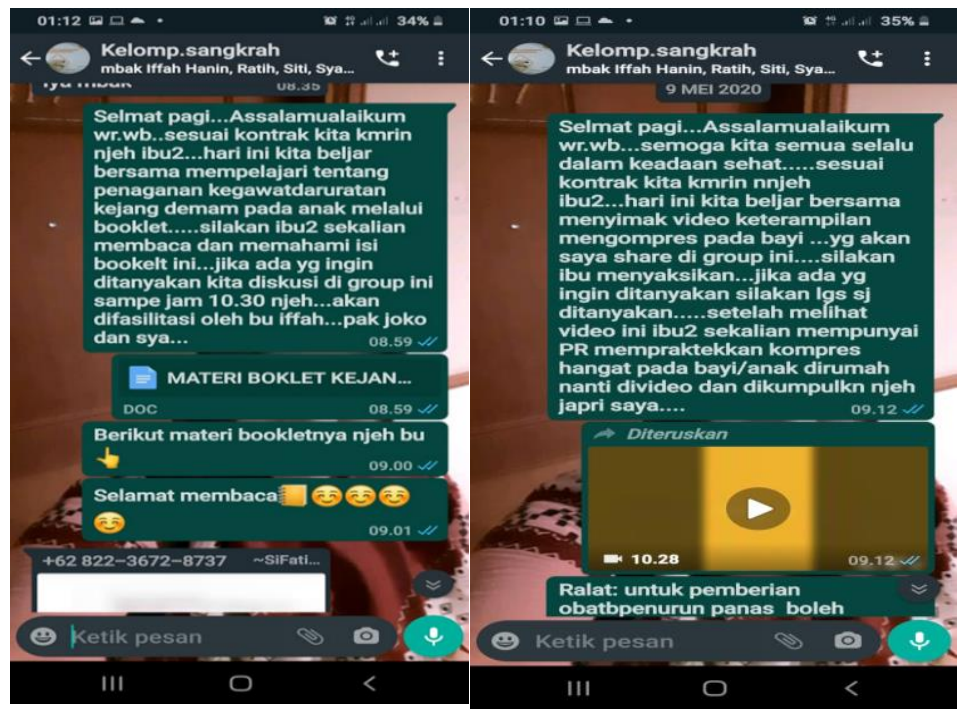

Gambar 2.6 Gambar penyampaian materi Kegiatan PKM

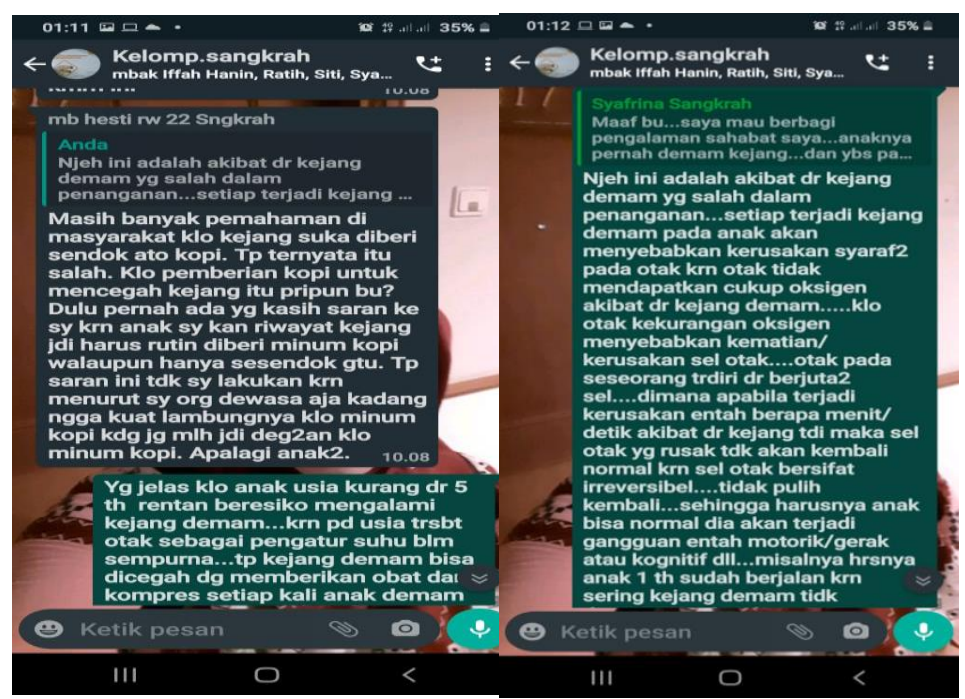

Gambar 2.7 Kegiatan diskusi dan tanya jawab materi secara online

\section{KESIMPULAN}

Berdasarkan hasil kegiatan pelatihan keterampilan penangan kejang demam dengan kompres WTS dan evaluasi hasil pretest pengetahuan dan ketrampilan maupun posttest pengetahuan dan keterampilan, dapat disimpulkan bahwa terdapat peningkatan pengetahuan dan ketrampilan kader Posyandu Puskesmas Sangkrah Surakarta.

Pengabdian masyarakat yang dilakukan di Puskesmas Sangkrah ini memanfaatkan media booklet untuk meningkatkan pengetahuan kader Posyandu dalam penanganan kejang demam dirumah dengan keterampilan kompres WTS. Kegiatan penyuluhan secara online dilakukan selama 4 kali kegiatan secara daring melalui Whatsapp Aplication Group (WAG) degan durasi 100 menit tiap pertemuan. Pelaksanaan juga diselingi dengan adanya sesi tanya jawab dari kader tentang materi yang diberikan sehingga ada feedback dari para kader Posyandu. 
Adanya peningkatan rata-rata nilai pengetahuan dan keterampilan kader Posyandu sebelum dan sesudah diberikan booklet menunjukkan bahwa responden memiliki kesadaran dan ketermpilan yang baik dibuktikan dengan hasil video yang dikirim sesuai dengan SOP yang telah ditentukan. Diharapkan booklet dapat dimasukkan ke dalam perencanaan kelas ibu dan anak di seluruh Posyandu wilayah Surakarta untuk meningkatkan derajad kesehatan anak karena terbukti booklet mampu meningkatkan pengetahuan, sikap dan keterampilan penagangan kegawatdaruratan kejang demam dirumah terutama di masa pandemi COVID-19.

\section{DAFTAR PUSTAKA}

Arifuddin Adhar. (2016). Analisis Faktor Risiko Kejadian Kejang Demam. Jurnal Kesehatan Tadulako, 2(2), 61.

Juwita, D. R. (2020). Makna Posyandu Sebagai Sarana Pembelajaran Non Formal Di Masa Pandemic Covid 19. Meretas: Jurnal Ilmu Pendidikan, 7(1), 1-15.

Marwan, R. (2017). Faktor Yang Berhubungan Dengan Penanganan Pertama Di Puskesmas ( Related Factors With The First Handling Of Febrile Convulsion In Female Children 6 Months - 5 Years In The Health Center ). 1(1), 32-40.

Pebrisundari, P. D. (2019). Pengaruh Pendidikan Kesehatan Dengan Media Leaflet Terhadap Pengetahuan Ibu Dalam Pertolongan Pertama Kejang Demam. In Poltekkes Denpasar. http://repository.poltekkesdenpasar.ac.id/2352/3/BAB II.pdf

Prasetyo, R., \& Siagian, T. H. (2017). Determinan Penyakit Berbasis Lingkungan Pada Anak Balita di Indonesia (Determinants Of Environmentally Based Diseases Among Children Under Five In Indonesia). Jurnal Kependudukan Indonesia, 12(2), 93-104.

Setyani, A., \& Khusnal, E. (2013). Gambaran perilaku ibu dalam penanganan demam pada anak di Desa Seran Kecamatan Gebang Purworejo. Aisyiyah Health Sciences Collage of Yogyakarta, 1-17. http://digilib.unisayogya.ac.id/549/

Suparjo, Fatchurrozak H, Nurcholis, C. (2019). Increasing The Ability Of Health Care Administrators In Handling The Fever Of The Fever Through Training For Early Crime Handling Peningkatan Kemampuan Kader Kesehatan Dalam Menangani Kejang Demam Melalui Pelatihan Penanganan Dini Kejang Demam diakibatkan. Jurnal Berkarya Pengabdian Pada Masyarakat, 1(2), 187-194.

Wardiyah, A., Setiawati, \& Romayati, U. (2016). Perbandingan Efektifitas Pemberian Kompres Hangat dan Tepid Sponge terhadap Penurunan Suhu Tubuh Anak yang Mengalami Demam di Ruang Alamanda RSUD dr . H . Abdul Moeloek Provinsi Lampung Tahun 2015. Jurnal Kesehatan Holistik, 10(1), 36-44. https://www.ejournal.unper.ac.id/index.php/PHARMACOSCRIPT/article/view/105

Wulandini, P., Saputra, R., \& Frilianova, D. (2019). Tingkat Pengetahuan Ibu Tentang Kejang Demam Pada Anak Usia 6 Bulan Sampai 5 Tahun Di Puskesmas Kampar Timur 2018. Jurnal Keperawatan Abdurrab, 2(2), 5767. https: / / doi.org/10.36341/jka.v2i2.625

Yuningsih, R. (2020). Promosi Kesehatan Pada Kehidupan New Normal Pandemi Covid-19. Info Singkat, XII no 11/(2088-2351), 13-18. 